\title{
Occupational asthma caused by chloramines in indoor swimming-pool air
}

\author{
K.M. Thickett*, J.S. McCoach*, J.M. Gerber ${ }^{\dagger}$, S. Sadhra , P.S. Burge*
}

Occupational asthma caused by chloramines in indoor swimming-pool air. K.M. Thickett, J.S. McCoach, J.M. Gerber, S. Sadhra, P.S. Burge. (C)ERS Journals Ltd 2002.

ABSTRACT: The first series of three workers who developed occupational asthma following exposure to airborne chloramines in indoor chlorinated swimming pools is reported. Health problems of swimmers in indoor pools have traditionally been attributed to the chlorine in the water. Chlorine reacts with bodily proteins to form chloramines; the most volatile and prevalent in the air above swimming pools is nitrogen trichloride.

Two lifeguards and one swimming teacher with symptoms suggestive of occupational asthma kept 2-hourly measurements of peak expiratory flow at home and at work, analysed using the occupational asthma system (OASYS) plotter, and/or had specific bronchial challenge testing to nitrogen trichloride, or a workplace challenge.

Air measurement in one of the pools showed the nitrogen trichloride levels to be $0.1-0.57 \mathrm{mg} \cdot \mathrm{m}^{-3}$, which was similar to other studies. Two workers had peak expiratory flow measurements showing occupational asthma (OASYS-2 scores 2.88 and 3.8), both had a positive specific challenge to nitrogen trichloride at $0.5 \mathrm{mg} \cdot \mathrm{m}^{-3}$ with negative challenges to chlorine released from sodium hypochlorite. The third worker had a positive workplace challenge.

Swimming-pool asthma due to airborne nitrogen trichloride can occur in workers who do not enter the water because of this chloramine. The air above indoor swimming pools therefore needs to be assessed and managed as carefully as the water. Eur Respir J 2002; 19: 827-832.
*Dept of Respiratory Medicine, Occupational Lung Diseases Unit, Heartlands Hospital, Birmingham, UK. Institut National de Recherche et de Securite, Vandoeuvre les Nancy Cedex, France. Institute of Occupationa Health, University of Birmingham, Birmingham, UK.

Correspondence: K.M. Thickett, Occupational Lung Diseases Unit, Dept of Respiratory Medicine, Heartlands Hospital, Bordesley Green East, Birmingham, B5 5SS, UK.

Fax: 441217720292

E-mail: kt01265702@blueyonder.co.uk

Keywords: Bronchial provocation test nitrogen trichloride

occupational asthma peak expiratory flow swimming pool

Received: March 32001

Accepted after revision October 21 2001
Chlorine releasing agents (calcium or sodium hypochlorite and chlorinated isocyanuric acids) are frequently used for the disinfection of water in swimming pools. The free chlorine reacts with pollutants introduced by humans, such as sweat and urine [1], to form aldehydes, halogenated hydrocarbons, and chloramines. Some of these compounds are transferred to the atmosphere above swimming pools, either as gases or droplets. LAHL et al. [2] described chemical reactions leading to the formation of chloramines, but emphasized that chloroform was the most common compound formed. Chloramines include the inorganic compounds chloramide (monochloramine $\left(\mathrm{NH}_{2} \mathrm{Cl}\right)$ ), chlorimide (dichloramine $\left(\mathrm{NHCl}_{2}\right)$ ), and nitrogen trichloride (trichloramine $\left(\mathrm{NCl}_{3}\right)$ ). The reaction that leads to the formation of inorganic chlorides [3] is:

$$
\begin{gathered}
\mathrm{NH}_{3}+\mathrm{HClO} \rightarrow \mathrm{NH}_{2} \mathrm{Cl}+\mathrm{H}_{2} \mathrm{O} \\
\mathrm{NH}_{2} \mathrm{Cl}+\mathrm{HClO} \rightarrow \mathrm{NHCl}_{2}+\mathrm{H}_{2} \mathrm{O} \\
\mathrm{NHCl}_{2}+\mathrm{HClO} \rightarrow \mathrm{NCl}_{3}+\mathrm{H}_{2} \mathrm{O}
\end{gathered}
$$

Nitrogen trichloride is predominant at a low $\mathrm{pH}(<8)$ and when there is a high chlorine/nitrogen ratio. Holzworth et al. [4] established Henry's law constants of the different chloramines and found that nitrogen trichloride was the species most likely to be found in swimming-pool atmospheres, whereas monoand dichloramines were more likely to be released in droplets produced by disturbance of the water surface. The irritating effects of indoor pool environments have been attributed to the presence of chloramines $[2,5]$ which cause irritant eye, nasal and throat symptoms, but no relationship has previously been found with bronchial hyperresponsiveness or asthma [6].

The aims of this study were: 1) to investigate whether nitrogen chloride can cause asthma amongst swimming-pool instructors and lifeguards; and 2) to measure typical nitrogen trichloride exposure levels in indoor swimming pools and generate these levels under laboratory conditions for provocation tests.

\section{Methods}

Workers were asked to record their peak expiratory flow (PEF) twice every hour from waking to sleeping for 4 weeks. The results were entered into occupational asthma system (OASYS)-2, a computer-assisted plotting and analytical system for the diagnosis of occupational asthma from serial PEF records. 
OASYS computes a score from $1-4$, indicating the likelihood of a work-related effect. A score $>2.5$ has a sensitivity of $75 \%$ and a specificity of $94 \%$ for a diagnosis of occupational asthma [7]. Peak flow recordings were considered to be satisfactory if there were four or more readings per day and three or more work-rest-work complexes, including three or more workdays in each work period, in the absence of intercurrent respiratory infections or change of treatment (W. Anees, Heartlands Hospital, Birmingham, UK, personal communication).

Nonspecific reactivity to histamine or methacholine was measured using the technique devised by YAN et al. [8] (normal $>8 \mu \mathrm{mol}$ ). Specific provocation tests were also performed, which involved the generation and measurement of nitrogen chloride under laboratory conditions [9].

\section{Generation of nitrogen chloride for provocation tests}

Gaseous nitrogen trichloride was formed by the combination of ammonium sulphate and sodium hypochlorite. The $\mathrm{pH}$, concentration and ratio are extremely important, as it is a potentially explosive mixture. The experiment was designed to produce nitrogen trichloride at a concentration of $0.5 \mathrm{mg} \cdot \mathrm{m}^{-3}$ in a challenge chamber, this concentration being at the upper end of the range measured in swimming pools $[1,6]$. Ten millilitres of ammonium sulphate solution $(0.432 \mathrm{~g}$ ammonium sulphate dissolved in $1,000 \mathrm{~mL}$ of water) was buffered to $\mathrm{pH} 3$ with citric acid and disodium hydrogen phosphate and added to the first Drecshel bottle. Immediately before the exposure an excess of sodium hypochlorite $(10 \mathrm{~mL}$ of a solution made from $5 \mathrm{~mL}$ of sodium hypochlorite in $100 \mathrm{~mL}$ of water) was added to the ammonium sulphate solution. The nitrogen trichloride was aspirated through two further Drecshel bottles. The first intermediate bottle contained $1 \%$ sulphamic acid to remove any chlorine vapours and the second bottle contained distilled water to trap any mono- or dichloramines. Fresh solutions were made up before each 10-min exposure. Air measurements of nitrogen trichloride were made during the challenge tests.

\section{Provocation tests}

On the first test day, three 10-min exposures to chlorine were performed, generated by painting a 1:20 dilution of sodium hypochlorite in water onto cardboard, sufficient to generate an estimated chlorine concentration of $0.5 \mathrm{mg} \cdot \mathrm{m}^{-3}$ (chlorine air measurements were not made during these challenges). On day 2, two 10-min exposures to nitrogen trichloride were performed. Spirometry was recorded at 5-min intervals for the first $30 \mathrm{~min}$ after each set of exposures, at 10 -min intervals for the next $30 \mathrm{~min}$, and then hourly until $12 \mathrm{~h}$ from the start of the test.

The lifeguard in case three had a workplace challenge test in which spirometry was measured at the poolside, using a Vitalograph spirometer (Vitalograph Ltd, Maids Moreton, Buckingham, UK). After establishing a baseline forced expiratory volume in one second (FEV1), the lifeguard was taken to the poolside for three 10-min exposures. FEV1 measurement consistent with standard European guidelines of acceptability and reproducibility [10] was performed after each exposure then every $5 \mathrm{~min}$ after the third exposure.

\section{Measurement of airborne levels of nitrogen trichloride}

The atmospheric nitrogen trichloride levels were measured at the poolside in case one and during the specific challenge tests. The sampling and analysis of nitrogen chloride was conducted using the method proposed by HERY et al. [1]. In brief the sampling device comprised of two parts: a tube containing silica gel coated with sulphamic acid to trap hypochlorite and mono- and dichloramine, and a cassette containing a quartz filter treated with sodium carbonate and diarsenic trioxide to trap nitrogen chloride. Sampling was conducted by drawing air through the sampling device using a calibrated pump operating at $1.1 \mathrm{~L} \cdot \mathrm{min}^{-1}$. After sampling, the quartz filter was desorbed in distilled water and the resulting solution analysed by ion chromatography using a cation exchange resin and a phthalic acid mobile phase adjusted to $\mathrm{pH} 4.2$. The sampling and recovery efficiency of the filters used has been reported to be $>95 \%$ [1].

A total of 15 samples for nitrogen chloride were collected in three indoor swimming pools over a 2-day period. Samplers were placed at positions normally occupied by the pool attendants, at $\sim 1 \mathrm{~m}$ from the floor level. The airborne nitrogen chloride concentrations were also measured during the challenge test with the sampler located close to the breathing zone. All sampling pumps were calibrated before and after collection of each sample.

\section{Results}

\section{Work histories}

Two workers were lifeguards and one was a swimming instructor in three different indoor swimming pools where the water was treated with sodium hypochlorite. They complained of cough and wheeze, which was worse at work, particularly if they were working by the poolside, and improved on days away from work. Table 1 shows their characteristics. They all had a long period of exposure before their first symptoms developed. A fourth chemical worker with occupational asthma, due to extreme sensitivity to formaldehyde, was challenged to nitrogen trichloride to investigate the specificity of the response.

Case one. A 42-yr-old female had worked as a swimming instructor for $10 \mathrm{yrs}$ when she developed wheeze, chest tightness, breathlessness, sore eyes, a dry throat and recurrent chest infections. Symptoms started within 20-120 min of arriving at work and were better on days away from work. The symptoms 
Table 1. - Patient characteristics

\begin{tabular}{|c|c|c|c|c|c|c|}
\hline Case & $\begin{array}{c}\text { Age at } \\
\text { presentation yrs }\end{array}$ & Occupation & Smoking status & Atopy ${ }^{\#}$ & Previous asthma & $\begin{array}{l}\text { Time from first } \\
\text { exposure to first } \\
\text { symptoms yrs }\end{array}$ \\
\hline
\end{tabular}

\begin{tabular}{|c|c|c|c|c|c|c|}
\hline 1 & 42 & Swimming instructor & Never & Yes & Yes & 10 \\
\hline 2 & 33 & Lifeguard & Never & Yes & Until age 11 yrs & 14 \\
\hline 3 & 49 & Lifeguard & Exsmoker 60 pack-yrs & No & No & 12 \\
\hline 4 & 44 & Industrial chemist & Exsmoker 10 pack-yrs & No & No & 3 \\
\hline
\end{tabular}

completely resolved when the subject was off work for 3 months following a hysterectomy, but recurred on return to work. Medication included $400 \mu \mathrm{g}$ budesonide twice daily and $200 \mu \mathrm{g}$ salbutamol as required. There was no prior history of eczema or hay fever. Skin tests to common environmental allergens showed strong positive reactions to house dust mite and grass pollen. The FEV1 was 2.51 (predicted 2.71) and the forced vital capacity (FVC) was 3.11 (predicted 3.11). There was no significant reversibility in FEV1 (2.81) to nebulized salbutamol. Following diagnosis, the subject was promoted to a job away from the swimming pool. At follow-up no nocturnal symptoms were reported, and the budesonide dose had been reduced to $100 \mu \mathrm{g}$ once daily and salbutamol was rarely used.

Case two. A 33-yr-old female who had worked as a lifeguard in a leisure centre for the previous $15 \mathrm{yrs}$ presented with a 1-yr history of wheeze, chest tightness, dry throat and sore eyes, which would begin within $1 \mathrm{~h}$ of starting work and persist for $1 \mathrm{~h}$ afterwards. After 6 months the subject started waking at night with wheeze and breathlessness, which only improved during periods away from work. Ventilation at the pool was felt to be poor. Medication included $400 \mu \mathrm{g}$ budesonide twice daily and $500 \mu \mathrm{g}$ terbutaline as required. There was no history of eczema or hay fever, although the subject had had asthma in childhood which had not required any treatment after the age of $11 \mathrm{yrs}$. Skin tests to common environmental allergens showed strong positive reactions to house dust mite and moderate reactions to cat dander and the moulds Cladosporium and Alternaria. White cell and eosinophil counts were normal. The FEV1 was 3.41 (predicted 3.41) and FVC 4.01 (predicted 3.81). There was no significant reversibility in FEV1 (3.51) to nebulized salbutamol. The subject was relocated away from the poolside but within the swimming-pool complex with no change in symptoms. Subsequently, the subject moved to work in a library and had no symptoms apart from occasional morning chest tightness. A terbutaline inhaler was available to use as required and the steroid inhaler was stopped altogether.

Case three. A 49-yr-old male worked as a swimmingpool lifeguard for 12 yrs without any respiratory problems. Following a respiratory tract infection the subject developed cough, wheeze and breathlessness, which were aggravated by exercise, car fumes, passive cigarette smoking and chest infections. Treatment included $600 \mu \mathrm{g}$ budesonide twice daily and $200 \mu \mathrm{g}$ salbutamol as required. The subject had previously smoked heavily (60 pack-yrs). Symptoms remained the same for 2 yrs. However, following recovery from a further respiratory tract infection within $10 \mathrm{~min}$ of being at the poolside the subject became breathless, extremely wheezy and had sore eyes. The subject had to leave the poolside immediately, and on one occasion the subject had to go straight to a general practitioner for nebulized therapy. The symptoms persisted for 1-2 $\mathrm{h}$ after leaving the pool. There was no history of eczema or hay fever and there was no family history of asthma. Skin tests to common environmental allergens were negative. White cell and eosinophil counts were normal. Spirometry revealed an FEV1 of 2.91 (predicted 3.41) and an FVC of 4.31 (predicted 4.31). Following nebulized salbutamol FEV1 fell to 2.71. The carbon monoxide transfer coefficient (KCO) was 1.63 (predicted 1.89 ) $\mathrm{mmol} \cdot \mathrm{min}^{-1} \mathrm{KPa}^{-1}$. On retirement, the symptoms improved and the subject was only breathless when walking on an incline. The subject was maintained on the same medication but rarely required inhaled salbutamol.

Table 2 shows the results of the PEF plots and challenge tests. No worker had increased nonspecific reactivity before the tests, although one was hyperresponsive before removal from work exposure. Two subjects completed satisfactory PEF measurements, which showed significant work-related changes with OASYS-2 analysis. One worker was unable to complete PEF measurements because of wheeziness within $30 \mathrm{~min}$ of arriving at the poolside and required a nebulizer (case three), making further exposures impossible. The swimming teacher's plot is shown in figure la and the plot of case two in figure $1 \mathrm{~b}$. Analysis after linearization and day interpretation using OASYS-2 showed scores of 3.8 and 2.88, respectively, within the definite occupational effect range. The challenges of cases one to three (figs. 2a-c) are shown with an unexposed control (fig. 2d), where a hyperresponsive patient with occupational asthma, reproduced by painting $0.1 \%$ formaldehyde, had a positive challenge to formaldehyde, and some response to nitrogen trichloride. All three swimmingpool workers had immediate asthmatic reactions to nitrogen trichloride (or swimming-pool air) and one had an additional late asthmatic reaction. None reacted to the chlorine exposure. The levels of nitrogen trichloride measured in the indoor swimming pool (case one) ranged from $0.23-0.57 \mathrm{mg} \cdot \mathrm{m}^{-3}$ in the 
Table 2.-Results of pre-/postchallenge histamine reactivity, bronchial challenge and occupational asthma system (OASYS)-2 score

\begin{tabular}{|c|c|c|c|c|c|c|}
\hline Case & $\begin{array}{c}\text { Previous } \\
\text { histamine } \\
\text { PD20 } \mu \mathrm{mol}\end{array}$ & $\begin{array}{l}\text { Prechallenge } \\
\text { histamine } \\
\text { PD20 }{ }^{\#} \text { mol }\end{array}$ & $\begin{array}{l}\text { Postchallenge } \\
\text { histamine } \\
\text { PD20 } \mu \mathrm{mol}\end{array}$ & $\begin{array}{l}\% \text { Maximum } \\
\text { immediate } \\
\text { fall in FEV } 1\end{array}$ & $\begin{array}{c}\% \text { Maximum } \\
\text { late fall } \\
\text { in FEV1 }\end{array}$ & $\begin{array}{l}\text { OASYS-2 } \\
\text { score }\end{array}$ \\
\hline $\begin{array}{l}1 \\
2 \\
3 \\
4\end{array}$ & $\begin{array}{c}>8 \\
1.5 \\
>8 \\
>4800 \mu \mathrm{g} \\
\text { methacholine }\end{array}$ & $\begin{array}{c}>8 \\
>8 \\
\text { Not done } \\
125 \mu \mathrm{g} \\
\text { methacholine }\end{array}$ & $\begin{array}{c}>8 \\
>8 \\
\text { Not done } \\
70 \mu \mathrm{g} \\
\text { methacholine }\end{array}$ & $\begin{array}{c}-45 \\
-27^{\oplus} \\
-14 \text { work challenge } \\
-15\left(\mathrm{NCl}_{3}\right) \\
-41 \text { (formaldehyde) }\end{array}$ & $\begin{array}{c}-48 \\
-6 \\
\text { Not done } \\
0\left(\mathrm{NCl}_{3}\right) \\
-4.1 \text { (formaldehyde) }\end{array}$ & $\begin{array}{c}3.8 \\
2.88 \\
\text { See text } \\
4.00\end{array}$ \\
\hline
\end{tabular}

\#: The prechallenge histamine test was performed within 2 days of being at work in case 3 , but in case 2 the worker had relocated to a library 1-yr previously. The worker previously had a positive histamine challenge when seen in the clinic whilst working as a lifeguard ( 2 days prior to the test) with a provocative dose causing a $20 \%$ fall in the forced expiratory volume in one second (FEV1) (PD20) of $1.5 \mu \mathrm{mol}$; ${ }^{\uparrow}$ : the worker had two challenges to nitrogen trichloride with 30 min exposure on consecutive days. The data shown in the table are for the second day following a 30-min exposure. On the first day, the maximum immediate reaction fall in FEV1 was $-17 \%$ at $20 \mathrm{~min}$ and maximum late reaction at 40 min was -15 .

smaller teaching pool where the subject worked, and from $0.1-0.31 \mathrm{mg} \cdot \mathrm{m}^{-3}$ in the main pool. Levels during the challenge tests were $0.5 \mathrm{mg} \cdot \mathrm{m}^{-3}$.

a)

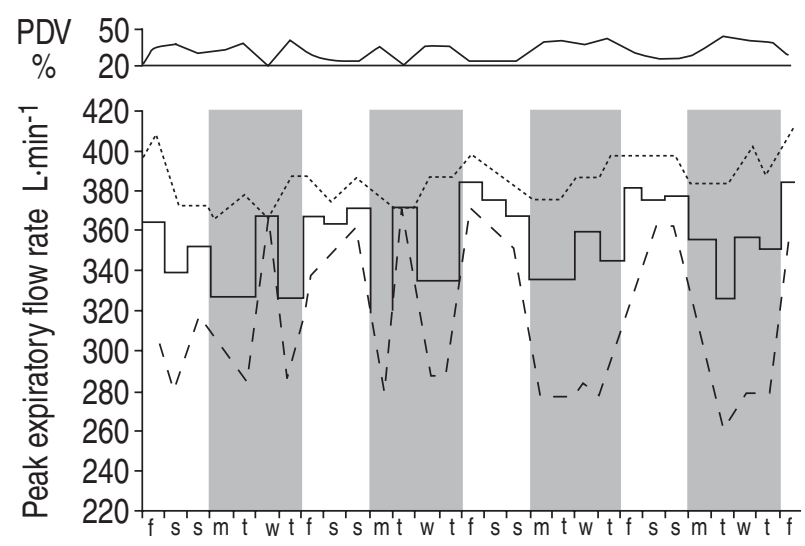

b)

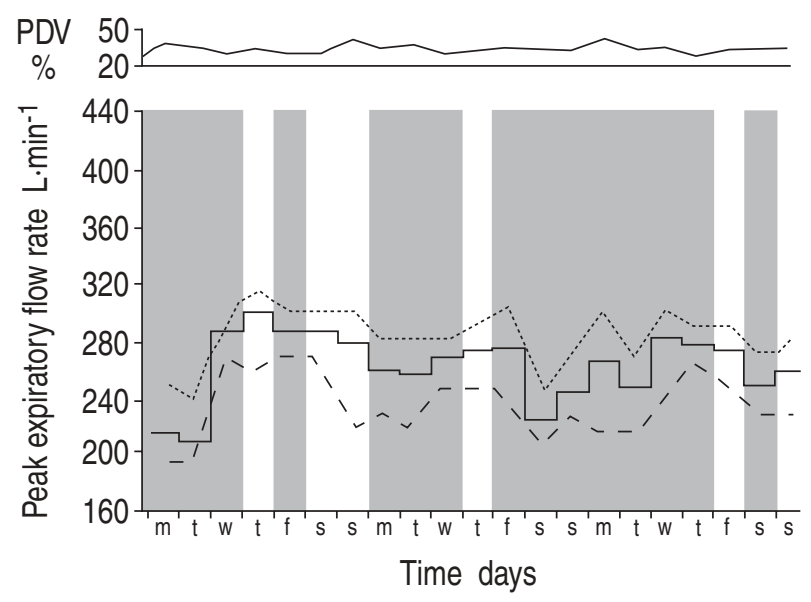

Fig. 1.-Occupational asthma system (OASYS) plot of a) a swimming teacher (case one) and b) a lifeguard (case two). .......... daily maximum peak expiratory flow rate; — : daily mean peak expiratory flow rate; - - - daily minimum peak expiratory flow rate. $\square$ : days away from work; $\square$ : days at work. PDV: percentage diurnal variation.

\section{Discussion}

The results show that nitrogen trichloride can be a cause of occupational asthma in swimming instructors and lifeguards. It was previously thought that chloramines only caused eye, nasal and throat symptoms. MASsIN et al. [6] studied 334 lifeguards working in 46 public swimming pools $(\mathrm{n}=228)$ and 17 leisure centre swimming pools. Nitrogen trichloride concentrations were greater in leisure pools (mean \pm SD, $0.67 \pm$ $\left.0.17 \mathrm{mg} \cdot \mathrm{m}^{-3}\right)$ than public pools $\left(0.24 \pm 0.37 \mathrm{mg} \cdot \mathrm{m}^{-3}\right)$, due to a higher air and water temperature, increased recycling of air pollutants and the use of a wave machine that created surface water disturbance. A dose/response relationship was found between nasal, eye and throat symptoms but not chronic respiratory symptoms. There was no correlation between bronchial hyperresponsiveness to methacholine and exposure to chloramines.

The mechanism of the occupational asthma due to nitrogen trichloride in the present cases was not, as is so often the case, completely clear. Some require measurement of nonspecific responsiveness outside the normal range before diagnosing asthma. In the authors' experience, specific reactivity to occupational sensitizers is commonly seen in workers with normal nonspecific reactivity [11]. Reactivity can return to normal after cessation of exposure. Case two was hyperresponsive at presentation, but had returned to normal before the specific challenge was performed $1 \mathrm{yr}$ after the last exposure, in keeping with removal from a sensitizing agent. The normal nonspecific reactivity before the challenge and the latent interval between first exposure and first symptom in the other two cases point to some form of specificity or hypersensitivity. Some would argue that the failure to induce nonspecific reactivity postchallenge is against a conventional immunoglobulin-E mediated reaction. One "nonexposed" worker (case four) was challenged with nitrogen trichloride using the same protocol. The worker had extreme sensitivity to formaldehyde and clinically reacted when working in a building some way from the nearest formaldehyde source. There was hyperresponsiveness to methacholine and a somewhat variable baseline. The worker's FEV1 

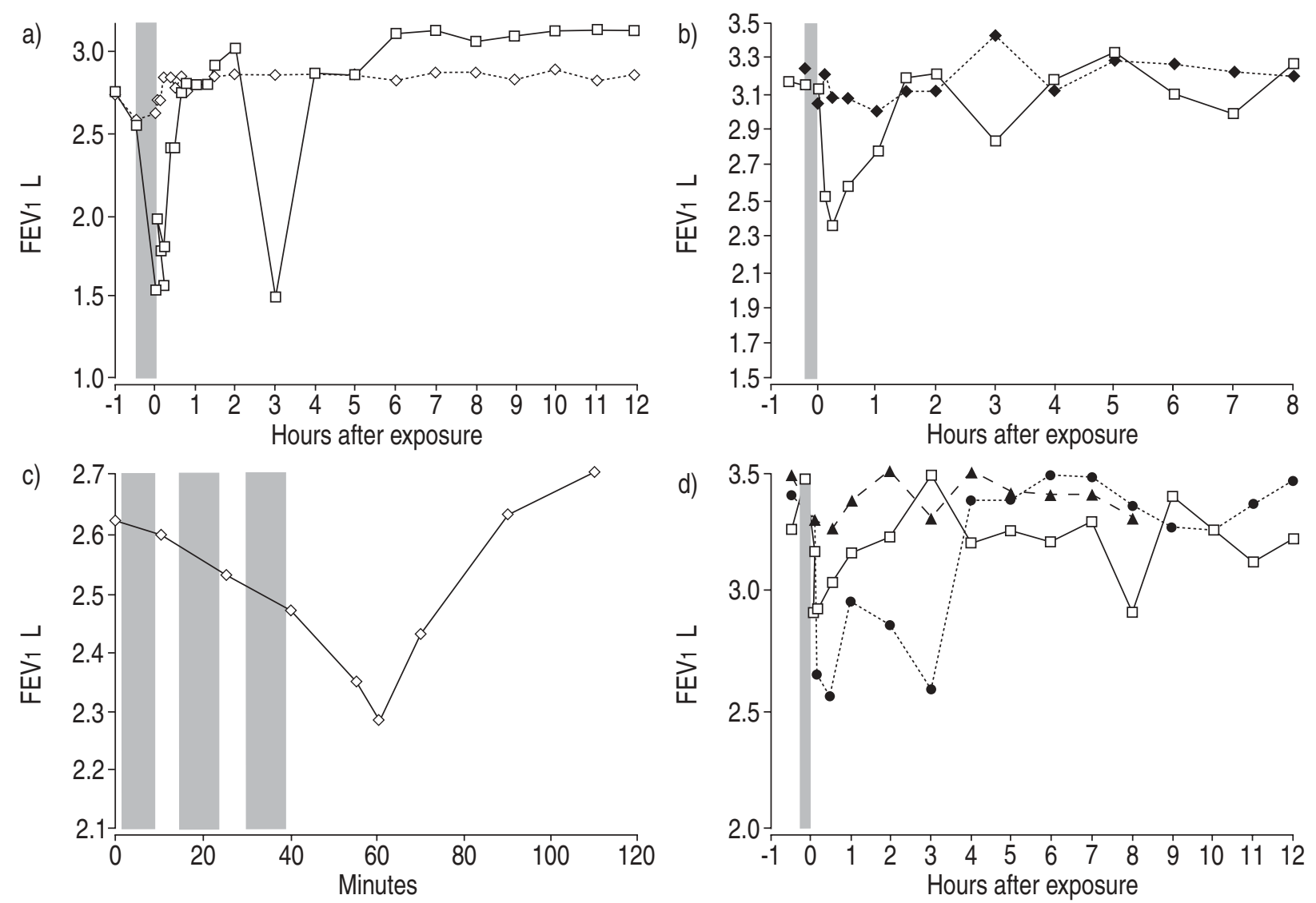

Fig. 2.-Bronchial challenge test to nitrogen trichloride and sodium hypochlorite in a) case one and b) case two. c) Poolside challenge test. d) Bronchial challenge test to nitrogen trichloride (control), water (control) and formaldehyde in an industrial chemist (case four). $\square$ : nitrogen trichloride; $\diamond$ : sodium hypochlorite; $\mathbf{0}$ : formaldehyde; $\boldsymbol{\Delta}$ : distilled water. Bars represent the challenge period.

probably did drop following nitrogen trichloride, which may represent a nonspecific, perhaps irritant, response, but its duration was longer than usually seen with an irritant. A further exposure to painted distilled water was carried out, which showed an insignificant fall in FEV1 (fig. 2d).

It is possible that nitrogen trichloride is a much more general cause of asthma. In a questionnairebased survey of 738 competitive swimmers, a high prevalence of respiratory symptoms was noted, including sneezing (45\%), breathing difficulty $(39.4 \%)$, coughing $(36.4 \%)$, sore eyes $(36 \%)$, wheezing $(26.3 \%)$, chest tightness $(34.8 \%)$ and chest congestion $(22.8 \%)$ [12]. Nearly $21 \%$ of swimmers who swam at international level reported asthma. Pоттs [12] compared bronchial responsiveness to methacholine in 35 competitive swimmers and 16 nonswimming athletes and found that $>60 \%$ of competitive swimmers demonstrated increased bronchial responsiveness to methacholine (provocative concentration causing a $20 \%$ fall in the FEV $1<16 \mathrm{mg} \cdot \mathrm{mL}^{-1}$ ), while only $12.5 \%$ of nonswimmers had similar results. Among the competitive swimmers, the prevalence of bronchial responsiveness was similar in those swimmers who had asthma and/or exercise symptoms suggestive of asthma $(61.1 \%)$ to those who had neither asthma nor symptoms $(58.8 \%)$. The authors have also seen two other workers who developed occupational asthma following exposure to chloramines. One patient worked as an endoscopy nurse and used sterilox (which contains ionized sodium chloride) to sterilize endoscopes, and the other worked as a forensic scientist. The latter developed symptoms whilst working at a database adjacent to a deoxyribose nucleic acid extraction area where a disinfectant containing chlorine was used. The symptoms abated when the patient worked in a mitochondrial laboratory that did not use the disinfectant. Both of these workers found they developed chest tightness if they visited an indoor swimming pool.

To conclude, nitrogen trichloride is a cause of occupational asthma. This should be considered when choosing chlorine-based disinfectants that are likely to come into contact with a nitrogen source. It should also be considered in anyone developing occupational asthma working at a swimming pool and is also a likely cause of asthma in those who swim in these pools. To prevent further cases, much more attention should be paid to the quality of air in indoor swimming buildings, as well as to the care of the chlorine content of the water.

\section{References}

1. Hery M, Hecht G, Gerber JM, Gendre JC, Hubert $\mathrm{G}$, Rebuffaud I. Exposure to chloramines in the 
atmosphere of indoor swimming pools. Ann Occup Hygiene 1995; 39: 427-439

2. Lahl U, Batjer K, Duszeln J, Gabel B, Stachel B, Thiemann W. Distribution and balance of volatile halogenated hydrocarbons in the water and air of covered swimming pools using chlorine for water disinfection. Water Res 1981; 15: 803-814.

3. Hailin GE, Wallace GG, O'Halloran RAJ. Determination of the trace amounts of chloramines by liquid chromatography separation and amperometric detection. Analyt Chim Acia 1990; 237: 149-153.

4. Holzworth G, Balmer RG, Sony L. The fate of chlorine and chloramines in cooling towers. Henry's law constants for flashoff. Water Res 1984; 18: 14211427.

5. Tchobanoglous G, Burton FL. Disinfection with chlorine compounds. In:: Eliasen R, King PH, Linsley RK, eds. Wastewater Engineering: Treatment Disposal. Reuse. 3rd Edn. New York, McGraw-Hill Inc., 1991; pp. 332-343.

6. Massin N, Bohadana AB, Wild P, Hery M, Toamain JP, Hubert G. Respiratory symptoms and bronchial responsiveness in lifeguards exposed to nitrogen trichloride in indoor swimming pools. Occup Environ Med 1998; 55: 258-263.

7. Gannon PFG, Newton DT, Belcher J, Pantin CF, Burge PS. The development of OASYS-2; a system for the analysis of serial measurement of peak expiratory flow in workers with suspected occupational asthma. Thorax 1996; 51: 484 489.

8. Yan K, Salone CM, Woolcock AJ. Rapid method for measurement of bronchial responsiveness. Thorax 1983; 38: 760-765.

9. McCoach JS, Sadhra S, Birell L, Burge PS. The preparation of nitrogen trichloride for a specific bronchial challenge. In: Raw G, Aizlewood C, Warren P, eds. Indoor Air. Volume 4. Proceedings of the 8th International Conference on Indoor Air Quality and Climate. London, Construction Research Communications Ltd, 1999; pp. 459-464.

10. Quanjer PH, Tammeling GJ, Cotes JE, Pedersen OF, Peslin R, Yernault JC. Lung volumes and forced ventilatory flows. Report Working Party Standardization of Lung Function Tests, European Community for Steel and Coal. Official Statement of the European Respiratory Society. Eur Respir J 1993; 6: Suppl. 16, 5s-40s.

11. Burge PS. Non-specific hyperreactivity in workers exposed to toluene diisocyanate, diphenyl methane diisocyanate and colophony. Eur J Pespir Dis 1982; 63: Suppl. 123, 91-96.

12. Potts JE. Adverse respiratory health effects of competitive swimming: the prevalence of symptoms, illness and bronchial responsiveness to metacholine and exercise (dissertation). University of British Colombia, Vancouver, 1994. 